Tarih Kültür ve Sanat Araştırmaları Dergisi

Revue des Recherches en Histoire Culture et Art مجلة البحوث التاريخية و الثقافية والفنية
Vol. 7, No. 5, December 2018

Copyright (C) Karabuk University

http://kutaksam.karabuk.edu.tr

\title{
DOI: 10.7596/taksad.v7i5.1888
}

Citation: Avcı, Y., \& Çiçek, S. (2018). Edilgen Çatılı Cümlelerin Nesirdeki Yeri. Journal of History Culture and Art Research, 7(5), 457-469. doi:http://dx.doi.org/10.7596/taksad.v7i5.1888

\section{Edilgen Çatılı Cümlelerin Nesirdeki Yeri*}

\author{
The Role of Passive Voice Structure in Turkish Prose Literature
}

\author{
Yusuf Avcı ${ }^{1}$, Sema Çiçek ${ }^{2}$
}

\begin{abstract}
This research aims to display to what extent the usage of the passive voice structure which we come accross frequently in recent in Turkish prose literature. In this research, the number of the sentences in the first fifty pages of different genres such as novels, stories or essays were examined and the rates of passive voice structure usage in these sentences were calculated. Additionally, the first ten pages of the dissertations were examined while the essays and columns in journals were examined totally within the scope of passive voice usage. The differences and the similarities in the usage of passive voice structure in the works written in different genres, in different times, about different subjects and by the writers who has different worldviews, are compared. The variables mentioned in previous sentence were also examined whether they have any effect on the usage of the passive voice.

As a result of the survey, less usage of the passive voice was detected in the writings which centered around events and actions than in the thought-based writings. It was also observed and obtained from the data gathered from the examined works that there is not an obvious difference between the amount of the usage of passive voice of the writers who have different philosophy, lifestyle or world view. Consequently, it is concluded that the usage of passive voice is an individual choice. It is known that Turkish society value the person and is famous for its being active, however the scociety is possibly in danger of losing its characteristics by widening the usage of the passive sentence structures since the event is more important rather than the person in passive voice. Therefore it should be said that the usage of passive voice is not appropriate for the active structure of Turkish society. Moreover, this passieveness faciliates the work of provocators in motivating the society to the negative movements.
\end{abstract}

Keywords: Passive voice sentence, Turkish prose literature, Active-pasive person, Syntax of Turkish language.

\footnotetext{
* Bu makale, INSLET “4. Uluslararası Dil Eğitimi ve Öğretimi Sempozyumu 26-28 Ekim Romanya"da gerçekleştirilen sempozyumda sözlü sunumu yapılan bildiriden genişletilerek hazırlanmıştır.

1 Çanakkale Onsekiz Mart Üniversitesi, Eğitim Fakültesi, Türkçe Eğitimi Bölümü, Türkiye. E-mail: yavci@comu.edu.tr

${ }^{2}$ Çanakkale Onsekiz Mart Üniversitesi, Eğitim Bilimleri Enstitüsü, Türkçe Eğitimi Bölümü, Türkiye. E-mail: sema.cck@windowslive.com
} 
Bu araştırma son zamanlarda sık sık karşılaştığımız edilgen çatılı cümle kullanımının nesirde ne boyutta olduğunu tespit etmeyi amaçlamaktadır. Araştırmada roman, hikâye, deneme gibi farklı türlerde yazılmış eserlerin ilk elli sayfasındaki cümle sayıları incelenerek bu cümlelerdeki edilgen çatı kullanım oranları hesaplanmıştır. Incelenen tezlerin ilk on sayfasında edilgen çatı kullanım oranlarına, makale ve köşe yazılarının ise tamamındaki cümle sayısına göre edilgen çatı kullanım oranlarına bakılmıştır. Farklı türlerde, farklı zamanlarda, farklı konularda ve farklı görüşlere sahip yazarlar tarafından yazılmış eserlerde edilgen çatılı cümle kullanım oranlarındaki benzerlikler ve farklıııklar karşılaştırımıştır. Bu çeşitli değişkenlerin edilgen çatılı cümle kullanımı üzerinde etkili olup olmadığı da tespit edilmeye çalışılmıştır.

Elde edilen bulgular, olay çevresinde gelişen yazı türlerinde edilgen yapılı cümle kullanımının düşünce yazılarına oranla daha az kullanıldığını göstermiştir. Ayrıca, taranan eserlerde farklı dünya görüşüne sahip farklı yazarların edilgen çatılı kullanım oranlarında bariz bir değişiklik olmadığı görülmüştür. Edilgen cümle yapısında öznenin geri plana atılması nedeniyle bu tür bir kullanımın, aktif olma ve insanı öne çıkartma özelliğiyle bilinen Türk toplumu için uygun olmadığı öngörülmüştür. Ayrıca edilgen olma kültürünün yaygın olduğu bir toplumda ortaya çıkabilecek toplumsal hareketlerde provokatörlerin çok daha rahat bir şekilde yönlendirme yapabileceği tespiti yapılmıştır.

Anahtar Kelimeler: Edilgen çatılı cümle, Türk nesirleri, Aktif-pasif insan, Türkçe'nin söz dizimi.

\section{Giriş}

Çoğu dilbilimci "çatı" kavramını fiilin özne ve nesneye göre durumu olarak değerlendirmiştir. Bazıları ise sadece eylem ve özne arasındaki ilişki olarak görmüştür (Yılmaz 2003). Banguoğlu (1995), çatıyı fiilin aldığı farklı görünümlerin özneye göre ilişkisi olarak değerlendirmiştir.

Korkmaz $(2003$, s. 61) çatı kavramını "Fiil kök veya gövdesinin sözlük anlamında herhangi bir değişikliğe uğramadan fiilden fiil yapan belirli bazı eklerle genişletilerek özne ve nesne ile olan bağlantısında uğradığı durum değişikliği; fiilin anlam değişikliği göstermeyen, ancak özne ve nesneye hükmeden şekil değişikliği" olarak tanımlanmaktadır. Hengirmen $(1995$, s. 202) ise "Eylemlerin nesne alıp almadıklarına ya da öznelerin durumuna göre çatı eklerinin eylem kök ya da gövdelerine getirilerek yeni eylem türetilmesine çatı denir" diye açıklamıştır.

Akerson'a göre çatı, cümle ögeleri arasındaki değer kaymalarına neden olur. Kişiler, cümlede hangi ögeyi önemsiyorlarsa onu vurgulamak istediklerinde ben, sen gibi zamirler kullanırlar veya vurgulamak istedikleri ögeyi yükleme yaklaştııılar. Önemsenen ögeyi öne çıkartılmanın başka bir yolu da çatı değişimidir. Çatı ögeler arasındaki değer farklılaşmasına neden olan dilsel işlemlerdir (Akerson, 2006'dan akt. Yılmaz, 2014).

Dil bilgisi kitaplarına ve yayımlanan akademik çalışmalara baktığımızda çatı kavramı genellikle yüklem olan fiilin yüklemi tamamlayan özne ve nesneyle olan ilişkisi olarak değerlendirilmiştir.

Muharrem Ergin çatı kavramını kullanmamış, çatı kavramı yerine fiilden fiil yapan ekler başlığı altında değerlendirmiştir. Zeynep Korkmaz ise fiilden fiil yapma eki olan çatı eklerini anlam değişikliği ve durum değişikliği yapan ekler olarak ikiye ayırmıştır (Korkmaz 2003).

Zeynep Korkmaz (2003, s. 547) edilgen çatı için "Fiil etken çatıdaki özne ve nesneyi almaz. Bu nedenle edilgen çatı öznesi belli olmayan, fiilin gösterdiği işin kimin tarafından yapıldığı bilinmeyen veya söylenmemiş olan çatıdır. Yalnız şu var ki, etken fiilin nesnesi edilgen çatıda bir özne görüntüsüne girmiştir" nesnenin özne kabul edildiği bir tanımlama yapmıştır. Ömer Demircan (2003, s. 13) "Öznesi 
etkilenen işlevli bir yüklem edilgen sayılıyor" şeklinde açıklarken, Muharrem Ergin (1998, s. 204) "Meçhul fiiller fail istemeyen, çekim sırasında faili olmayan, gösterdiği hareketin kimin tarafından yapıldığı belli olmayan fiillerdir" diye tanımlar. Muhsine Börekçi (2004, s. 490) ise "Geçişli bir fiili geçişsiz yaptığı söylenen -(I)l eki, kılışın nesnesinin dil bilgisel özne konumuna geçtiğini gösterir, nesneyi ortadan kaldırmaz. Aynı ek geçişsiz bir file geldiğinde özne açııından belirsizliğin oluşmasının nedeni budur" diyerek geçişli-edilgen çatıda nesnenin varlığını benimsemiştir.

Türk dilinde edilgen çatı, cümlenin yüklemi olan fiilin morfolojik yapısının -I- ve $n$ - yardımıyla değiştirilmesi sonucu oluşmaktadır (Korkmaz, 2003). Türkçede edilgenlik, eylem kök ve gövdelerine genellikle $\{-1\} /\{-n\}$ eklerinden uygun olan biri getirilerek yapılır. Edilgenlik ekinin temel işlevi, özneyi bilinmez kılmak, bu eylemin kurduğu cümlelerde öznenin yüzey yapıya çıkmasına engel olmaktır. Bir başka deyişle özneyi cümle dışında atmaktır. "Çocuk vuruldu", "Bina boyandı" örneklerinde yüklemde yer alan edilgenlik eki, bu işlevdedir (Üstünova, 2006). Çocuğun kimin tarafından vurulduğu, binanın kimin tarafından boyandığı bilinmez; özne cümle dışına atılmıştır.

Yüklemi edilgen çatılı fiillerden oluşan cümlelerde fiildeki iş, oluş ve hareketin kim tarafından yapıldığı belli olmadığı için yani özne belli olmadığı için bu tür cümlelerin düz tümlecine sözde özne denir (Dizdaroğlu, 1976; Şimşek, 1987; Hatipoğlu, 1982; Ediskun, 1999; Koç, 1996; Bozkurt, 1995; Hengirmen, 1995; Paçacıoğlu, 1987).

Sözde özne terimi yerine Ahmet Topaloğlu (1989) gramerce özne, Zeynep Korkmaz (2003) görünür özne veya gramerce özne terimini kullanmıştır. Tahir Kahraman (1996) bu özne türünü anlatımca özne terimiyle adlandırır. Tahsin Banguoğlu (1995) güçte kimse olarak adlandırırken Osman Bolulu (1992) ise, bu tür özneleri öznesizlik olarak adlandırmıştır.

Son yıllarda 'Üretici-Dönüşümsel' dil bilim çalışmalarının Türkiye'de tanınmaya başlamasıyla edilgen çatı ile ilgili çalışmalara daha çok yer verilmeye başlanmışır. Dil bilimcilerimiz şimdiye kadar edilgen yapının daha çok cümledeki işlevselliği ve söz dizimi üzerinde dururken edilgen yapının anlamsal boyutu eksik kalmıştır (Karabulut, 2012). Chomsky'nin ortaya attığı Üretici-Dönüşümsel ekole ve Saussure'nin Yapısalcı ekolüne göre araştırmalar yapılmış olsa da bu ekoller yetersiz kalır; çünkü bu ekoller batı dilleri esas alınarak kurulmuştur. Türk dilinin anlam merkezli olarak ele alınması gerekir. Bu anlamda aslında Fıtrat (1927), Türk düşünce sistemine uygun olarak dilin önce anlam bütünlüğünü ele alır sonra yüzeysel yapıyla dilin öğretimi ve incelenmesine geçer. Muhtemeldir ki Fıtrat'ın öldürülmesinden sonra Chomsky onun eserinden yararlanarak Fıtrat'ın ekolüne kendi adını vererek bu ekolü sadece Batı dillerine uyarlar (Avcı, 2012). Çünkü Fıtrat'ın Nahiv ${ }^{3}$ adlı eserinin anlam merkezli bir yaklaşımla cümleyi incelediğini görüyoruz.

Aslında edilgen çatıyı anlamsal boyutta ele almak en az söz dizimini incelemek kadar önemlidir. Çünkü edilgen çatılı cümlelere anlamsal olarak baktığımızda Türk düşünce yapısına ve kültürüne aykııı bir yapıya sahip olduğu görülmektedir. Edilgen çatı anlamsal olarak batı dillerinin düşünce yapısına uygundur. Her millet kendi yapısına ve kültürüne uykun kullanımlar benimsemelidir.

Türk dili tarih boyunca çeşitli nedenlerden dolayı yabancı dillerin etkisi altında kalmıştır ve kalmaya devam etmektedir. Din değişikliğinden sonra İslam kültürüyle birlikte Arap ve Fars dillerinin etkileri, bağlama edatlarının Türkçenin cümle yapısına etkisi dilimizin bu alanda gördüğü ilk olumsuz etkilerdendir. Bu etkilerden sonra bu olumsuzluklar artarak devam etmiştir (Avcl, 2013). Tanzimat'la birlikle ise Batı dillerindeki gramer mantığı özellikle Fransızcanın gramer kalıpları Türkçenin yapı ve işleyiş özelliklerini etkilemiştir (Avcı, 2013). Batılılar, tarih boyunca yayılmacı politikalarını toplumların dillerini etkileyebilmek adına önce toplumun kültür sahasında başlatmışlardır. Örneğin; ülkemizde yabancı dille eğitim

\footnotetext{
${ }^{3}$ Nahiv'i 1993 yılında Taşkent'teki kütüphanelerde ve ilgili kişilerde bulamadım. Daha sonra kitabın izini sürerek Amerika'da Şikago Üniversitesi, kataloglanmamış kitaplar arasından bularak temin edebildim. Y.A.
} 
yapılmasının sebeplerini sonuçlarına bakarak görebiliriz. Avrupa ülkelerinde yabancı dille eğitim yapılmaz. Batııılar başka ülkelerde yabancı dille eğitim yaptıırlar. Bunun yanında yabancı dil öğretimi yaparken bile kendi kültürlerini, yaşama ve düşünce şekillerini aktarırlar. Karşılarında bunları hiç düşünmeden kabul eden, taklit eden yığınlar oluşturmuş olurlar (Avcı, 2012).

Günümüzde, teknolojinin gelişmesiyle insanlar arasındaki mesafe ortadan kalkmıştır. Bu durum farklı kültürleri ve bu kültürlerin değer yargılarını, düşünce yapılarını öğrenme imkânı sağlamıştır. Yalnız çoğu durumda sadece öğrenmekle kalmayıp genç nesillerin etkilenmesi de söz konusu olmaktadır. Hatta bu etkilenme taklitçiliğe kadar ilerleyip adına da modernleşme denilmeye başlamıştır. Bu durumda zamanla Türk milli değerleri, düşünce yapısı, kültürel özellikleri bozulmakta ve yabancı unsurların etkisi altında kalmaktadır. Özellikle genç nesillere baktığımızda bu bozulmalar açık olarak görülür. Türkçe karşılı̆ı olan yabancı kelimeleri yabancı haliyle kullanmayı tercih etmek, Batılı kültürleri kolay öğrenip taklit etmek, yabancı markaları tercih etmek, yabancı isimli mekânları tercih etmek, milletimizin söz varlı̆ı zenginliklerini kullanmamak, anlamsal ve dil bilgisel olarak Batı dillerine uygun kuralları kendi dilimizde kullanmaya çalışmak taklitçiliğin en önemli göstergelerindendir. Her milletin dili o milletin özünden bir parçadır, o milletin yansımasıdır. Milletlerin dillerine bakarak o milletlerin düşünce yapılarını ve kültürlerini görebiliriz. Dil ve kültürdeki bu gibi bozulmalar düşünce yapılarının da bozulmasına neden olmaktadır.

Edilgen çatılı cümleler yabancı etkilerle dilimize girmiş ve yabancı kurallara, düşünce yapılarına uygun bir kullanımdır. Bugün Türkçede de bu kullanımın olduğunu göz önüne alırsak Türk dili yabancı dillerden olumsuz yönde etkilenmiştir diyebiliriz. Başlangıçta Türk kültürü yabancı kültürlerin etkisinde kalmış ve kültür yozlaşması dili etkilemiştir. Çünkü dil ve kültür birbirinden ayrı düşünülemeyecek iki önemli kavramdır. Dil ve düşünce yozlaşması cümle yapısını bozmaya başlamıştır.

Türkçede öncelikle yargı düşünülür daha sonra yardımcı unsurlar düşünülür. Ancak ilk düşünülen temel unsur sonda yer almaktadır. Yüklemi tamamlayııı yardımcı unsurlar ise yüklemin anlatım eksikliğini tamamlayarak başta yer alır. Yani cümlenin en sonunda bulunan yüklem aslında en çok önemsenen unsurdur. Fakat yüklemin içerisinde özneyi de barındırdığı düşünüldüğü zaman özne yüklemden de önce gelir diyebiliriz. Yüklemin son eki şahıs ekidir yani bütün cümleler aslında şahıs ekiyle biter. Bu durumda aslında en önemli unsur insandır.

Edilen çatıı cümlelerin kullanım alanı yazı dilidir, konuşma dilinde edilgen çatılı cümleler daha az kullanılmaktadır. Günlük konuşma dilinde kurduğumuz cümle örneklerine bakacak olursak herhangi bir kaza olduğunda "Kaza yapıldı" şeklinde bir kullanım yerine "Ayşe kaza yaptı" şeklinde bir kullanımla karşılaşııı. Kaza değil, kazayı kimin yaptığı önemlidir. Herhangi bir sınav sonucu açıklandığında "90 alınmış" yerine "Fatma 90 almış" şeklinde bir kullanımla karşılaşırız. Alınan en yüksek puanın kaç olduğu alan kişi kadar önemli değildir. Türk düşünce yapısında kişinin önemini nesneden daha önce geldiğini günlük hayattaki pek çok örnekte görmek mümkündür. Konuşma dilinde, derin yapıdaki cümle aynı şekilde yüzey yapıya çıktığı için edilgen çatıı cümle kullanımı yok denecek kadar azdır. Fakat yazı dilinde aynı durum söz konusu değildir. Edilgen cümlelerde özneyi dışlamak esas olduğu için konuşma dilinde bunu yapmak daha zordur çünkü Türk düşünce yapısında özne çok önemli bir yere sahip olduğundan etken cümleler ağızdan çıkmaktadır. Oysa yazı dilinde düşünce yapısına çok önem verilmez. Etken cümlelerle düşünülmesine rağmen yazıya geçirirken farklı sebeplerden dolayı edilgen cümleler kullanılmaktadır.

Edilgen yapıların asıl kullanım alanı yazı dilidir. Bu nedenden dolayı edilgen yapıların anlamsal bakımdan işlevselliğini, kullanılmak istenen metinlerin hangi amaçla yazıldığı belirler. Edilgen yapıların yer aldığı metinler incelendiğinde edilgen yapının bazı metin türlerinde özellikle daha çok tercih edildiği görülmüştür (Karabulut, 2012).

1. Bilimsel içerikli makaleler 


\section{Bilimsel tezler}

3. Bilimsel inceleme ve araştırma kitapları

4. Teknolojiyle ilgili metinler ve teknolojik alanlar

5. Ders kitapları

Yukarıdaki listeyi uzatmak mümkündür; ancak listeden de anlaşılacağı gibi edilgen yapılı kuruluşlar, genellikle bilimsel ve teknolojik alanları içeren yazılı metinlerde kullanılmaktadır. Bunun nedeni bilimsel içerikli metinleri oluşturan araştırmacı ya da araştırmacıların (metni gerçekleştiren öznenin/edicinin/failin) kendilerini metinden soyutlama ve dışlama çabalarıdır. Edilgen yapılarda özneyi cümleden dışlamak ya da öznenin cümledeki önemini azaltmak esas olduğundan bilimsel metinlerde anlamsal içeriği oluşturmak için edilgen yapıların tercih edildiği görülür. Bilimsel metinlerin eleştiri, yorumlama ve kanıtlanabilirlik yönlerinden hâlâ sorgulanabilir bir niteliğinin olması da edilgen yapıların kullanılmasında etkili olmaktadır (Karabulut, 2012). Ancak bu yoruma katılmak doğru değildir metnin türü ne olursa olsun edilgen yapılı cümle kullanım oranında herhangi bir değişiklik olmaması gerekmektedir.

Ağız incelemesi yapmak için bölgelerden derlenmiş metinlerdeki cümlelerde edilgen çatılı cümleler \% 0,1 civarındadır. Bengütaşlarda hiç edilgen çatılı cümle yokken Nutukta da \% 0,1 oranındadır (Avcı, 2010). Nutuk, söylev niteliği taşıyan bir eser olmasına rağmen edilgen çatılı kullanım çok azken günümüzde bilimsel metinlerde bu oranın çok yüksek olması kabul edilebilir bir durum değildir. Taklitçiliğin olmadığı, kültürel özelliklerin bozulmadığı o dönemlerde yazarların da dilimize sahip çıktıkları görülür. Türk dil bilgisine uygun olmayan edilgen çatılı cümlelerin kullanılmaması bunun en güzel örrneğidir.

Dünya'nın en eski ve en büyük dillerinden olan Çincede edilgenlik bugünkü anlamıyla son yüzyıllarda ortaya çıkmıştır. Eski zamanlarda bei (maruz kalmak) fiili yardımıyla edilgenlik kuran Çince, sadece olumsuz durumların ifade edilmesinde bu yola başvurmuşken, bugün araştırmacıların belirttiğine göre özellikle Batı dillerinin tesiri ile daha geniş bir yelpazede edilgenlik kullanmaya ve bei olumsuz fiilini de olumlu hale getirmeye başlamıştır (Karabulut, 2012). Örnekte de görüldüğü gibi yabancı dillerin etkisiyle bozulan bir yapısal değişim söz konusudur. Her dil kendi kültürü ve düşünce yapısına göre değerlendirilmelidir. Bu durumun zaman içerisinde bozulmalara neden olmasına izin verilmemelidir.

\section{Yöntem, Bulgular ve Değerlendirme}

Seçilen nesirlerde dikkate alınan temel değişken eserlerin türüdür. Farklı türdeki eserlerde kullanılan edilgen çatılı cümle oranlarında benzerlik olup olmadığı tespit edilmeye çalışılmıştır. Diğer değişkenler ise eserlerin konusu ve yazarların sağ/sol, madde/ruh, toplum/birey görüşleridir. İncelenen nesirler; beş roman, bir öykü, üç deneme, dört köşe yazısı, iki makale ve iki tezdir. Eserlerdeki edilgen çatılı cümle kullanım oranları roman, öykü ve denemelerde ilk elli sayfasındaki toplam cümle sayısına, tezlerde ilk on sayfadaki toplam cümle sayısına göre istatistikler çıkartılmıştır. Köşe yazısı ve makalelerin ise tamamındaki cümleler esas alınmıştır. Oranlar alınırken etken çatılı cümle ve eksiltili cümle bir tutularak sadece edilgen çatılı cümleler değerlendirilmiştir.

Tablo 1. Öykü ve romanlar, öykü ve romanların özellikleri, edilgen çatılı cümle sayı/oranları

\begin{tabular}{|c|c|c|c|c|c|c|}
\hline Yazar & Kitap & Basım yılı & Türü & $\begin{array}{l}\text { İlk } 50 \\
\text { sayfadaki } \\
\text { cümle sayısı }\end{array}$ & $\begin{array}{l}\text { Edilgen } \\
\text { çatılı cümle } \\
\text { sayısı }\end{array}$ & $\begin{array}{l}\text { Edilgen } \\
\text { çatılı cümle } \\
\text { kullanım } \\
\text { oranı }\end{array}$ \\
\hline Hüseyin Nihal & Bozkurtlar & 94 & $\mathrm{~nm}$ & 1036 & & $\% 42$ \\
\hline
\end{tabular}




\begin{tabular}{llccccc}
$\begin{array}{l}\text { Fakir } \\
\text { BAYKURT }\end{array}$ & $\begin{array}{l}\text { Amerikan } \\
\text { SargıIı }\end{array}$ & 1967 & Roman & 2202 & 24 & $\% 1,08$ \\
Tarık BUĞRA & Osmancık & 1973 & Roman & 1219 & 25 & $\% 2,05$ \\
Emine IŞıNSU & Sancı & 1974 & Roman & 1274 & 36 & $\% 2,8$ \\
Ferid EDGÜ & Çığık & 1982 & Öykü & 1088 & 9 & $\% 0,8$ \\
$\begin{array}{l}\text { Orhan } \\
\text { PAMUK }\end{array}$ & Kar & 2002 & Roman & 745 & 17 & $\% 2,3$ \\
\hline
\end{tabular}

Hüseyin Nihal Atsız'ın "Bozkurtlar Diriliyor" adlı romanının ilk elli sayfasını incelediğimizde tespit ettiğimiz 1036 cümlenin 44 tanesi edilgen çatılı cümledir. Bu da oran olarak \%4,2 gibi bir orana karşılık gelmektedir. Sağ görüşe olan yatkınlığıyla bilinen yazar edilgen çatı kullanımı konusunda diğer yazarlara göre daha cüretkâr davranmıştır. Tarihi bir roman olan kitap Türklerin en hareketli dönemleri olan Göktürk Dönemini anlatıyor olması yönüyle edilgen çatılı cümle kullanımının da olabildiğince az olması gerekirken diğer olay yazılarına göre daha fazla kullanıldığı görülmektedir.

Fakir Baykurt'un "Amerikan Sargısı" adlı romanının ilk elli sayfasını incelediğimizde tespit ettiğimiz 2202 cümlenin 24 tanesi edilgen çatılı cümledir. Bu da oran olarak \%1,08 gibi bir orana karşılık gelmektedir. Baykurt, toplumsal sorunları görmezden gelmeyen bir zihniyete sahip olduğunda eserlerinde toplumun sorunlarını ele almıştır. Devrimci bir görüşe sahip olan yazarın bu romanında bariz bir edilgen yapının olmadığı görülmektedir.

Tarık Buğra'nın "Osmancık” adlı romanını incelediğimizde tespit ettiğimiz 1219 cümlenin 25 tanesi edilgen çatılı cümledir. Bu da oran olarak \%2,05 gibi bir orana karşılık gelmektedir. Tarafsız çizgisini hiç bozmayan Tarık Buğra bu romanında Osmanlı́nın büyük bir devlet haline gelişi öyküleyici bir anlatımla anlatılmıştır. Edilgen yapı kullanım oranının ortalama bir değer olduğu görüyoruz.

Yine yakın tarihlerde yazıımış Emine Işınsu'nun "Sancı" adlı romanını incelediğimizde tespit ettiğimiz 1274 cümlenin 36 tanesi edilgen çatılı cümledir. Bu da oran olarak \%2,8 gibi bir orana karşlık gelmektedir. Ülkücü bir gencin mücadelesini konu alan ve devrin buhranlarını sade bir dille anlatan sağ görüşteki yazar 1974 ' te yazdığı bu eserde edilgen çatıyı ortalama bir değerde kullandığını görüyoruz.

Ferit Edgü'nün "Çığlık" adlı öyküsünü incelediğimizde tespit ettiğimiz 1088 cümlenin 9 tanesi edilgen çatılı cümledir. Bu da oran olarak \%0,8 gibi bir orana karşılık gelmektedir. İncelediğimiz eserler içinde en düşük edilgen çatılı cümle kullanım oranı Ferit Edgü’ye aittir. Eserin türünün öykü olmasıyla edilgen çatı kullanımının az olması bağdaştıramayacağımız iki durumdur çünkü tabloda yer alan romanlarda öykü gibi olay çevresinde gelişen türlerdendir. Bu durumu eserin konusuyla ilişkilendirebiliriz. Çünkü "Çığlık" ruh çatışmasını konu edindiği için bireysel fikirlerin öne çıktığı bir eserdir. Bireyin öne çıkıyor olması edilgen çatıyı ikinci plana attığı için bu eserdeki kullanımın da az olduğu görülmektedir.

Nobel Ödüllü yazar Orhan Pamuk'un "Kar" adlı romanını incelediğimizde tespit ettiğimiz 745 cümlenin 17 tanesi edilgen çatılı cümledir. Bu da oran olarak \%2,3 gibi bir değere karşılık gelmektedir. Orhan Pamuk'un diğer yazarlara oranla cümlelerini çok uzun tuttuğunu söyleyebiliriz. Bu kadar uzun cümle kurmak Türk diline hâkim olamayışın bir göstergesidir. Sol görüşe olan yatkınlığıyla bilinen yazarın edilgen çatılı cümle kullanım oranı için ortalama bir değer olduğunu söyleyebiliriz. 
Farklı dünya görüşüne sahip farklı yazarların kaleme aldığı olay çevresinde gelişen edebi türlerden olan roman ve öyküye baktığımızda edilgen çatılı kullanım oranlarında bariz bir değişiklik olmadığı görülmektedir. Romanlarda farkı siyasi görüşlere sahip yazarların aşağı yukarı aynı sayıda edilgen çatılı cümle kullandıklarını tespit ettik. Aynı siyasi görüşe sahip yazarların bazen kullanımları birbirine yakınken bazen tam tersi de olabilmektedir. Yine romanların konularına baktığımızda tarihi konulu olanlar da toplumsal olanlarda da benzerlik ve farklılıklar değişkenlik göstermektedir. O zaman edilgen yapı kullanımının daha bireysel bir olgu olduğu gibi bir sonuca ulaşabiliriz.

Tablo 2. Denemeler, denemelerin özellikleri ve edilgen çatılı cümle sayı/oranları

\begin{tabular}{lllllll}
\hline Yazar & Kitap & Basım yılı & Türü & $\begin{array}{l}\text { ilk } \\
\text { sayfadaki } \\
\text { cümle sayısı }\end{array}$ & $\begin{array}{l}50 \\
\text { Edilgen } \\
\text { çatılı cümle } \\
\text { sayısı }\end{array}$ & $\begin{array}{l}\text { Edilgen çatılı } \\
\text { cümle } \\
\text { kullanım } \\
\text { oranı }\end{array}$ \\
\hline $\begin{array}{l}\text { Nurullah } \\
\text { ATAÇ }\end{array}$ & $\begin{array}{l}\text { Karalama } \\
\text { Defteri }\end{array}$ & 1952 & Deneme & 837 & 6 & $\% 0,71$ \\
$\begin{array}{l}\text { Nihad SamiRLI } \\
\text { BANA }\end{array}$ & $\begin{array}{l}\text { Türkçenin } \\
\text { Sirları }\end{array}$ & 1972 & Deneme & 490 & 34 & $\% 6,93$ \\
KAPLAN & Kültür ve Dil & 1982 & Deneme & 699 & 52 & $\% 7,43$ \\
\hline
\end{tabular}

Nurullah Ataç'ın "Karalama Defteri" adlı denemesinin ilk elli sayfasını incelediğimizde tespit ettiğimiz 837 cümlenin sadece 6 tanesi edilgen çatılı cümledir. Bu da oran olarak \%0,71 gibi çok düşük bir orana karşılık gelmektedir. Deneme dediğimiz tür kişinin kendi düşüncelerini ifade ettiği özneyi ön plana çıkaran bir kullanımın daha çok hâkim olması gereken bir tür olduğu için bu oran bizi şaşırtmamaktadır.

Nihad Sami Banarlı'nın "Türkçenin Sırları” adı denemesinin ilk elli sayfasını incelediğimizde tespit ettiğimiz 490 cümlenin 34 tanesinin edilgen çatılı cümle olduğu görülmüştür. Bu da oran olarak \%6,93 gibi oldukça fazla bir orana karşılık gelmektedir.

Mehmet Kaplan'ın "Kültür ve Dil” adlı denemesinin ilk elli sayfasını incelediğimizde tespit ettiğimiz 699 cümlenin 52 tanesinin edilgen çatılı cümle olduğu görülmüştür. Bu da oran olarak $\% 7,43$ gibi bir orana karşılık gelmektedir. Bu oran incelediğimiz denemeler arasında en yüksek orandır.

Düşüncelerin açık şekilde dile getirildiği bir tür olan denemede Nurullah Ataç'ın "Karalama Defteri" dışında edilgen çatılı cümle kullanım oranlarının çok yüksek olduğu görülmektedir.

Tablo 3. Köşe yazıları, köşe yazılarının özellikleri ve edilgen çatılı cümle sayı/oranları

\begin{tabular}{lllllll}
\hline Yazar & Gazete & Başlığı & Tarihi & $\begin{array}{c}\text { Cümle } \\
\text { sayısı }\end{array}$ & $\begin{array}{l}\text { Edilgen } \\
\text { çatılı } \\
\text { cümle } \\
\text { sayısı }\end{array}$ & $\begin{array}{l}\text { Edilgen } \\
\text { çatılı } \\
\text { cümle } \\
\text { kullanım } \\
\text { oranı }\end{array}$ \\
\hline $\begin{array}{l}\text { Melis } \\
\text { ALPHAN }\end{array}$ & Hürriyet & $\begin{array}{l}\text { 50 Yı Önce İnsana } \\
\text { Verilen Değer }\end{array}$ & 13.04 .2017 & 26 & 5 & $\% 20$ \\
$\begin{array}{l}\text { Abbas } \\
\text { GÜÇLÜ }\end{array}$ & Milliyet & $\begin{array}{l}\text { YGS 9.45 Mağdurlarına } \\
\text { Yeni Sınav Hakkı }\end{array}$ & 13.04 .2017 & 32 & 5 & $\% 16$ \\
Rahim ER & Türkiye & Terörle Mücadele & 13.04 .2017 & 43 & 9 & $\% 21$
\end{tabular}


Melis Alphan'ın Hürriyet Gazetesinde 13.04.2017 tarihinde kaleme aldığı “50 Yıl Önce İnsana Verilen Değer" adlı 26 cümlelik köşe yazısında 5 cümlenin edilgen olduğu görülmüştür. Bu oran \%20 gibi bir değere karşılık gelmektedir.

Abbas Güçlü 'nün Türkiye Gazetesinde 13.04.2017 tarihinde kaleme aldığı "YGS 9.45 Mağdurlarına Yeni Sınav Hakkı" adlı 32 cümlelik köşe yazısında 5 cümlenin edilgen olduğu görülmüştür. Bu oran \%16 gibi bir değere karşılık gelmektedir.

Rahim Er'in Türkiye Gazetesinde 13.04.2017 tarihinde kaleme aldığı "Terörle Mücadele" adlı 43 cümlelik köşe yazısında 9 cümlenin edilgen olduğu görülmüştür. Bu oran \%21 gibi bir değere karşılık gelmektedir.

Mevlüt Tezel'in Sabah Gazetesinde 13.04.2017 tarihinde kaleme aldığı "Boşanmanın Zevki" adlı 17 cümlelik köşe yazısında 2 cümlenin edilgen olduğu görülmüştür. Bu oran \%12 gibi bir değere karşılık gelmektedir.

Köşe yazısı da düşünce yazılarındandır. İncelediğimiz aynı tarihteki farklı gazetelere ait, farklı konularda yazılmış köşe yazılarının hepsinde edilgen çatılı cümle kullanımının çok yüksek olduğunu gördük.

Tablo 4. Makaleler, makalelerin özellikleri ve edilgen çatılı cümle sayı/oranları

\begin{tabular}{llllll}
\hline $\begin{array}{l}\text { Makalenin } \\
\text { yazarı }\end{array}$ & Makalenin adı & Yayımlandığı yıl & $\begin{array}{l}\text { Toplam cümle } \\
\text { sayısı }\end{array}$ & $\begin{array}{l}\text { Edilgen çatılı } \\
\text { cümle sayısı }\end{array}$ & $\begin{array}{l}\text { Edilgen çatılı } \\
\text { cümle kullanım } \\
\text { oranı }\end{array}$ \\
\hline Gönül içLi & $\begin{array}{l}\text { Küreselleşme } \\
\text { ve Kültür } \\
\text { Türk Kimliğini } \\
\text { Oluşturan } \\
\text { Ortak Kültürel } \\
\text { Değerler }\end{array}$ & 2001 & 161 & 40 & $\% 25$ \\
\hline
\end{tabular}

Gönül İçli'nin 2001 yılında yazdığı "Küreselleşme ve Kültür” adlı makale 161 cümleden oluşmaktadır. Bu cümlelerin 40 tanesi edilgen yapıdadır. Bu oran \%25' e denk gelmektedir.

Osman Özkul'un 2015 yılında yazdığı "Türk Kimliğini Oluşturan Ortak Kültürel Değerler" adlı makale 341 cümleden oluşmaktadır. Bu cümlelerin 88 tanesi edilgen yapıdadır. Bu oran \%24' e denk gelmektedir.

Tablo 5. Tezler, tezlerin özellikleri ve edilgen çatılı cümle sayı/oranları

\begin{tabular}{|c|c|c|c|c|c|}
\hline Tezin yazarı & Tezin adı & Yayımlandığı yıl & $\begin{array}{l}\text { Illk } 10 \text { sayfadaki } \\
\text { cümle sayısı }\end{array}$ & $\begin{array}{l}\text { Edilgen çatılı } \\
\text { cümle sayısı }\end{array}$ & $\begin{array}{l}\text { Edilgen çatılı } \\
\text { cümle kullanım } \\
\text { oranı }\end{array}$ \\
\hline \multirow{3}{*}{ Zeynep KOCA } & Türkiye & & & & \\
\hline & Türkçesinde Fiil & & & & \\
\hline & $\begin{array}{l}\text { Çatılarının } \\
\text { İşlevsel } \\
\text { Özellikleri }\end{array}$ & 2004 & 121 & 31 & $\% 26$ \\
\hline
\end{tabular}




\begin{tabular}{llllll}
\hline \multirow{3}{*}{ Burcu ASLAN } & Eski Türkçeden & & & \\
& Türkiye & 2009 & 104 & 41 & \\
& Türkçesine Çatı & & & \\
& Ekleri & & & \\
\hline
\end{tabular}

Zeynep Koca'nın 2004 yılında yayımlanan "Türkiye Türkçesinde Fiil Çatılarının Işlevsel Özellikleri” adlı tezinin ilk on sayfasını incelediğimizde tespit ettiğimiz 121 cümlenin 31 tanesi edilgen çatılı cümledir. Bu da oran olarak \%26 gibi bir orana karşlık gelmektedir.

Burcu Aslan'ın 2009 yılında yayımlanan "Eski Türkçeden Türkiye Türkçesine Çatı Ekleri” adlı tezinin ilk on sayfasını incelediğimizde tespit ettiğimiz 104 cümlenin 41 tanesi edilgen çatılı cümledir. Bu da oran olarak \%40 gibi bir orana karşılık gelmektedir.

Farklı tarihlerde farklı kişiler tarafından farklı konularda yazılmış bilimsel yazılardan olan makale ve tezlerdeki edilgen çatılı kullanım oranları birbirine yakındır. Bu türlerdeki edilgen çatı kullanımı ortalamanın çok üzerindedir. Özellikle tezlerde incelediğimiz bütün eserler içinde en yüksek oranların olduğunu söyleyebiliriz.

Çalışmanın ikinci aşamasında toplumunda edilgen çatı kullanımıyla ilgili yanlış bir algı olup olmadığını tespit etmek amacıyla tek bir anket sorusunu toplumun her kesimine ulaşmak adına internet ortamında sorarak 273 katıımcıya ulaştık. Katılımcıların demografik özellikleri aşağıda tablolar halinde verilmiştir. Sorduğumuz sorunun cevaplarına göre de sorunun yorumlaması yapılmıştır.

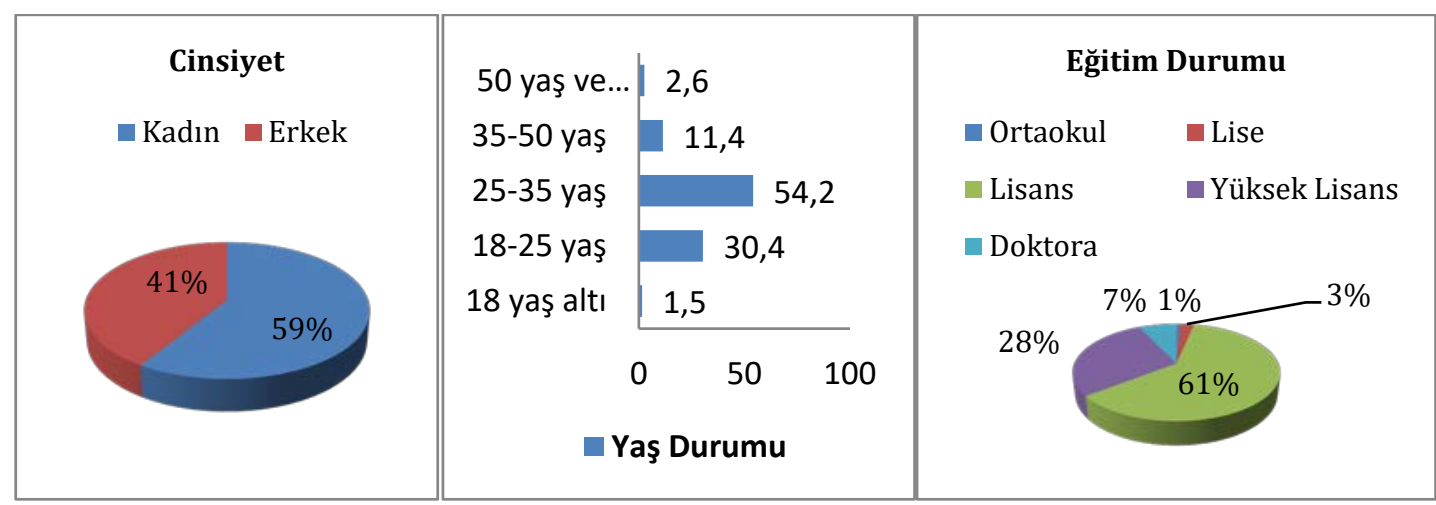

Yaptığımız anket çalışmasından elde ettiğimiz verilerden yola çıkarak araştırma sorusunun \%59'unu kadın katıımcılar, \%41'ini erkek katılımcılar cevaplamıştır. Kadın katıımcıların soruları cevaplama oranları daha fazladır.

Katıımcıların yaş aralıklarına baktı̆̆ımızda \%54 gibi yüksek bir oranla $25-35$ yaş olduğu görülmektedir. Onu \%30,4 ile 18-25 yaş aralığı izler. \%11,4 35-50 yaş, \%2,6 50 yaş ve üzeri, $\% 1,5$ ise 18 yaş altı katııımcı bulunmaktadır.

Katılımcıların eğitim durumuna baktığımızda en yüksek oranı \%61'le lisans mezunlarının oluşturmaktadır. $\% 28$ 'inin yüksek lisans, $\% 7$ 'sinin doktora, $\% 33^{\prime u ̈ n u ̈ n ~ l i s e ~ v e ~ \% 1 ' i n i n ~ o r t a o k u l ~ m e z u n u ~ o l d u g ̆ u ~ d i g ̆ e r ~}$ bulgulardır. 


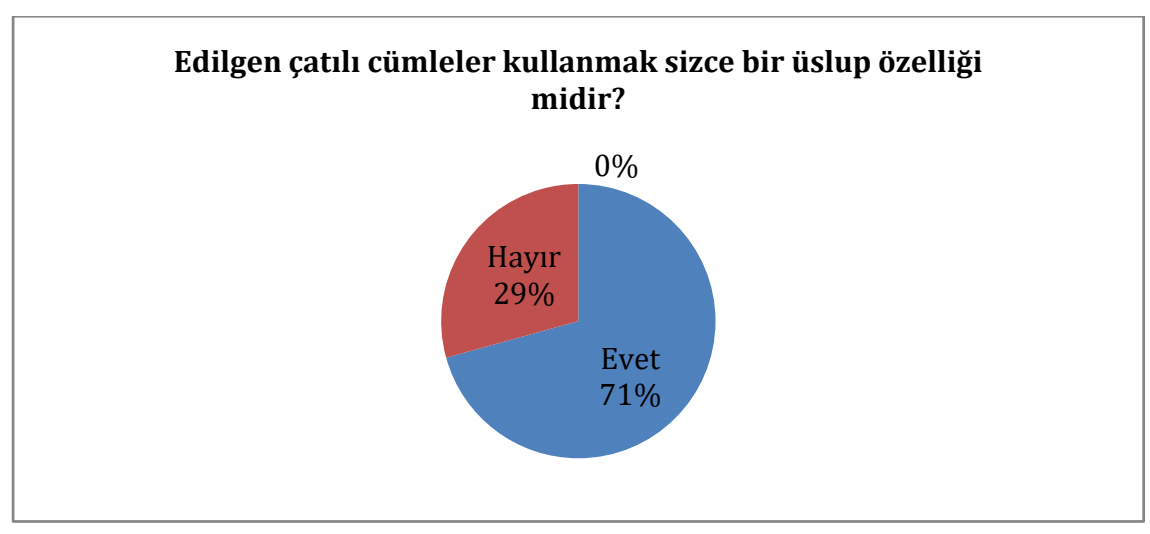

“Edilgen çatılı cümleler kullanmak sizce bir üslup özelliği midir?” sorusuna katılımcılar \%71 oranında evet, $\% 29$ oranında hayır cevabını vermiştir.

Toplumda edilgen çatının bir üslup özelliği olduğuna dair yanlış bir algı söz konusudur. Ankete katılanların \%71'i gibi büyük bir oranı edilgen çatıyı üslup özelliği olarak değerlendirir. Bu algı sosyolojik bir gerçeği yansıtmaktadır. Edilgen cümle yapısı Türk dilinin bir üslup özelliği olmamasına rağmen yanlış algı oluşturularak bir yaşama şekliymiş gibi sunulmaktadır. Bunun için incelediğimiz metinlerde kullanım oranlarının hayli yüksek olduğu saptanmıştır.

Dünya dillerinde edilgenlik konusunda çalışmaları olan Siewierska, dilleri edilgenliğin sahip olup olmadıklarına göre sınıflamış ve buna bağlı olarak etken edilgen diller haritası çıkarmıştır. $O$, çalışmasında 373 dili incelemiş, bu dillerden 211 'inde edilgen yapının olmadığını, 162'sinde edilgenliğin bulunduğunu tespit etmiştir. Bu konu çerçevesinde büyük dil ailelerinin neredeyse tamamına incelenmiştir. Geriye kalan diller küçük ve büyük ölçüde veri sunmayan diller (Karabulut, 2012) olarak yer almıştır.

\section{Sonuç ve Öneriler}

İncelediğimiz farklı türdeki metinlerde genel olarak edilgen çatılı cümle kullanımlarının fazla olduğunu gördük. Özellikle deneme, köşe yazısı gibi düşünce yazılarıyla makale ve tez gibi bilimsel yazılarda daha yüksek oranda edilgen çatılı cümle yer almışır. Düşünce yazılarında yazarın edilgen çatı kullanımıyla kendisini pasifleştirmesi doğru değildir. Aksine kendisini öne çıkararak ileri sürdüğü yargının sorumluluğunu alması beklenir. En fazla edilgen çatı kullanımı bilimsel yazılardadır. Bilim yapmak kendine güveni ve aktif olmayı gerektirirken bilimsel metinlerde bu kadar fazla edilgen yapı kullanımı kişiyi silik yapar, zayıf düşürür. Romanlarda ve öyküde, düşünce yazılarına ve bilimsel yazılara oranla daha az edilgen çatılı cümle kullanılmıştır. Bu durum yazarın duygusalığın ve doğallığının daha az bozulmasıyla açıklanabilir. Temeldeki bu artışların nedeni toplumdaki düşünce ve kültür değişikliğidir. Cümle yapısındaki olumsuz değişmelerin temel sebebinin bu etkileşim olduğunu görüyoruz.

Teknolojinin hızlı bir şekilde gelişmesiyle farklı kültürlerle olan iletişim imkânı da artmıştır. Bunun olumlu sonuçlarının yanında olumsuz sonuçları da vardır. Farklı kültürleri, dilleri öğrenmek güzelken bu kültür ve dilleri taklit ederek kendi özünden uzaklaşmak doğru değildir. Özellikle genç nesiller bu ayrımın farkına varacak durumda olmadıklarından çok kolay taklitçiliğe kaçabilmektedirler. Zamanla da bu taklitçilik kendi dilimize aitmiş gibi algılanıp bir sonraki nesillerin yadırgamaması sağlanmaktadır. En tehlikeli değişim yavaş yavaş olandır. Bu sebeple geç olmadan bazı şeylerin farkına varılıp düzeltilmesi gerekmektedir. Değişimler ve taklitler kültürel olabileceği gibi dil bilgisel de olabilmektedir.

Türkçenin yargı merkezli bir dil olduğu unutulmamalıdır ve yabancı dillerin özelliklerinin Türk diline yansımasını önlemek için önlemler alınmalıdır. İster düşünce yazıları olsun isterse olaya dayalı metinler 
olsun etken çatılı cümleler tercih edilmelidir. Türk düşünce yapısının nesneden çok özneyi önemsediği gerçeğinden hareketle cümleler kurulmalıdır. İnsanlar bu konuda biliçlendirilmelidir.

Etken çatılı cümlede işi yapan ve yüklemin içinde anlamsal olarak yer alan özne, edilgen cümlelerde önemini yitirerek yerini nesneye devretmektedir. Geçmişte Türk kültürüne ve yaşayış tarzına baktığımızda Türklerin atlı göçebe bir toplum olduğunu yani aktif ve hareketli olma odaklı yaşadıklarını söyleyebiliriz. Oysaki edilgen çatılı cümlelere anlam olarak baktı̆̆ımızda öznenin geri plana atılmasından kaynaklı bir pasiflik olduğu görülmektedir. Yani aslında Türkçede insanın bütün unsurlardan önemli olduğu, şahıs ekinin cümledeki yeriyle karakteristik özelliği ortaya çıkmış olur.

Etken çatılı cümleler kuran bir toplumla edilgen çatılı cümleler kuran bir toplumun davranış ve düşünceleri arasında büyük farklar vardır. Edilgen çatılı cümleler kuran toplumlarda bir pasiflik bir söz konusudur. İnsanın nesne karşısındaki değeri düşüktür. Türkler insanı önemser, değer verir ve yardımseverliği üst düzeydedir. Bu özellikleri etken çatılı cümlelere yansır.

Görüldüğü gibi bu küçük gibi görünen dil bilgisiyle ilgili ayrıntılar zaman içerisinde sosyolojik değişmelerle birlikte büyük problemlere neden olabilmektedir. Türk dilinin düşünce yapısına uygun olmayan her kullanım zamanla milleti benliğinden uzaklaştırmakta, değişimlerin uzun vadeli olduğunu düşündüğümmüzde yozlaşmalar yavaş yavaş gerçekleşmektedir. Düşünceye dayalı değişimlerin sonucunda kolay devşirilen bir toplum yapısının ortaya çıktığına her yönüyle şahit oluyoruz.

Ele aldığımız cümleleri dil düşünce çerçevesinde değerlendirdiğimizde dil toplum ilişkisi öne çıkmaktadır. Aktif, canlı, edilgen olmayan bir toplum yapısı için Türkçe söz ve metinlerde olabildiğince edilgen yapıı cümleler azaltılmalıdır. Toplumunu etken çatılı cümle kullanmaya teşvik ederek, etken çatılı cümlelerin kalıcılığının, kişilik veya üslup özelliğine dönüştürülmesinin sağlanması gerekmektedir.

\section{Kaynakça / References}

Alphan, M. (2017, 13 Nisan). 50 yıl önce insana verilen değer. Hürriyet. http://www.hurriyet.com.tr/ adresinden alındı.

Aslan, B. (2009). Eski Türkçeden Türkiye Türkçesine çatı ekleri. Gazi Üniversitesi, Ankara.

Ataç, N. (1998). Karalama defteri. i̇stanbul: Yapı Kredi Yayınları.

Atsız, H. N. (1998). Bozkurtlar diriliyor. İstanbul: Irfan Yayınevi.

Avcl, Y. (2012). Türk dillerinin öğretiminde teori sorunu ve cümlenin etkinlik-edilgenlik yapısı üzerine düşünceler. Hüseyin Karasayev'in Doğumunun Yüz Onuncu Yılı Münasebetiyle Düzenlenen Uluslararası Bilimsel Sempozyum-Bişkek Gumanitardık Üniversiteli- 29.02.2012 BişKEK. (55)

Avcı, Y. (2013). Türkçede cümle öğretiminde ortaya çıkan sorunlar. 11. Uluslararası Türk Dünyası Sosyal Bilimler Kongresi, s. 701-708.

Avcı, Y. \& Korkmaz, N. (2010). Yabancı dil ve kültürlerin siyasi amaçlarla Türkçenin cümle yapısına etkisi. II Uluslararası Türkiye Eğitim Araştırmaları Kongresi, s. 1329-1337.

Banarlı, N. S. (2012). Türkçenin sırları. İstanbul: Kubbealtı Yayınları.

Banguoğlu, T. (1995). Türkçenin grameri. Ankara: Türk Dil Kurumu Yayınları.

Baykurt, F. (2007). Amerikan sargısı. İstanbul: Literatür Yayınları. 
Bolulu, O. (1992). Eylemler ve özneler üzerine bir anlam incelemesi. Türk Dili Dergisi, 32, s.46-52.

Bozkurt, F. (1995). Türkiye Türkçesi. İstanbul: Cem Kültür Yayıncılık.

Börekçi, M. (2004). Türkçe öğretimi bakımından çatı kavramı. V. Uluslararası Türk Dili Kurultayı Bildirileri I içinde (s. 487-499). Ankara: TDK Yayınları.

Buğra, T. (2014). Osmancık. Ankara: Ötüken Yayınları.

Demircan, Ö. (2003). Türk dilinde çatı. İstanbul: Papatya Yayıncılık.

Dizdaroğlu, H. (1976). Tümcebilgisi. Ankara: Türk Dil Kurumu Yayınları.

Duru, M. Ö. (2008). Türk dilinde edilgen çatı (tarihi-karşılaştırmalı bir durum çalışması). Yayımlanmamış yüksek lisans tezi. Ondokuz Mayıs Üniversitesi, Sosyal Bilimler Enstitüsü, Samsun.

Edgü, F. (1997). Çığlık. İstanbul: Yapı Kredi Yayınları.

Ediskun, H. (1999), Türk dilbilgisi. İstanbul: Remzi Kitabevi.

Er, R. (2017, 13 Nisan). Terörle mücadele. Türkiye. http://www.turkiyegazetesi.com.tr/ adresinden alındı.

Gencan, T. N. (1979). Dilbilgisi. Ankara: Türk Dil Kurumu Yayınları.

Güçlü, A. (2017, 13 Nisan). YGS 9.45 mağdurlarına yeni sınav hakkı. Milliyet. http://www.milliyet.com.tr/ adresinden alındı.

Hatipoğlu, V. (1982) Türkçenin sözdizimi. İstanbul: Dergah Yayınları.

Hengirmen, M. (1995). Türkçe dilbilgisi. Ankara: Engin Yayınları.

Işınsu, E. (2012). Sancı. İstanbul: Bilge Kültür Sanat.

İçli, G. (2001). Küreselleşme ve kültür. Sosyal Bilimler Dergisi, 25(2), s. 163-172.

Kahraman, T. (1996). Çağdaş Türkiye Türkçesi dilbilgisi. Ankara: DuMat Basımevi.

Kaplan, M. (2002). Kültür ve dil. Ankara: Dergah Yayınları.

Karabulut, F. (2012). Türk dilinde ve dünya dillerinde edilgen yapı tipolojisi dilbilimsel bir inceleme. Ankara: Grafiker Yayınları.

Koca, Z. (2004). Türkiye Türkçesinde fiil çatılarının işlevsel özellikleri. Erciyes Üniversitesi, Kayseri.

Koç, N. (1996). Yeni dilbilgisi. İstanbul: İnkılap Kitapevi.

Korkmaz, Z. (2003). Gramer terimleri sözlüğü. Ankara: TDK Yayınları.

Korkmaz, Z. (2003). Türkiye Türkçesinde fiil çatısı üzerine görüşler. Türk Dili Araştırmalar Yıllığı-Belleten 2001/I-II, s. 193-198.

Özkul, O. (2015). Türk kimliğini oluşturan ortak kültürel değerler. HAK-iŞ Uluslararası Emek ve Toplum Dergisi. 4(8), s. 167-185.

Paçacıoğlu, B. (1987). Türk dili dersleri. Ankara: Cumhuriyet Üniversitesi Yayınları. 
Pamuk, O. (2006). Kar. İstanbul: İletişim Yayınları.

Şimşek, R. (1987). Örneklerle Türkçe sözdizimi. Trabzon: Kuzey Gazetecilik Matbaaclık.

Tezel, M. (2017, 13 Nisan). Boşanmanın zevki. Sabah. https://www.sabah.com.tr/ adresinden alındı.

Topaloğlu, A. (1989). Dil bilgisi terimleri sözlüğü. İstanbul: Ötüken Yayınları.

Üstünova, K. (2000). Yüklem, yalnız özneyi mi içinde taşır? Sosyal Bilimler Dergisi, 11(11), s. 241-250.

Yıldız, M. (2014). Eski Türkçede işlevsel bağlamda çatı ekleri. Yayımlanmamış yüksek lisans tezi. Eskişehir Osmangazi Üniversitesi, Sosyal Bilimler Enstitüsü, Eskişehir.

Yılmaz, E. (2003). Türkiye Türkçesinde ikili çatı sorunu ve bunun öğretimi ile ilgili meseleler. Türk Dili Araştırmaları Yıllığı-BELLETEN, 2001/I-II, s. 251-2001.

Yücel, B. (1999). Türkiye Türkçesinde fiil çatıları, Türk Gramerinin Sorunları II, TDK Yayınları, Ankara, 1999. 